Reimagining the Role of School Libraries in STEM Education: Creating Hybrid Spaces for Exploration

Author(s): Mega M. Subramaniam, June Ahn, Kenneth R. Fleischmann, Allison Druin

Reviewed work(s):

Source: The Library Quarterly, Vol. 82, No. 2 (April 2012), pp. 161-182

Published by: The University of Chicago Press

Stable URL: http://www.jstor.org/stable/10.1086/664578

Accessed: 19/03/2012 22:38

Your use of the JSTOR archive indicates your acceptance of the Terms \& Conditions of Use, available at http://www.jstor.org/page/info/about/policies/terms.jsp

JSTOR is a not-for-profit service that helps scholars, researchers, and students discover, use, and build upon a wide range of content in a trusted digital archive. We use information technology and tools to increase productivity and facilitate new forms of scholarship. For more information about JSTOR, please contact support@jstor.org. 


\title{
REIMAGINING THE ROLE OF SCHOOL LIBRARIES IN STEM EDUCATION: CREATING HYBRID SPACES FOR EXPLORATION
}

\author{
Mega M. Subramaniam, ${ }^{1}$ June Ahn, ${ }^{2}$ Kenneth R. Fleischmann, ${ }^{3}$ \\ and Allison Druin ${ }^{4}$
}

In recent years, many technological interventions have surfaced, such as virtual worlds, games, and digital labs, that aspire to link young people's interest in media technology and social networks to learning about science, technology, engineering, and math (STEM) areas. Despite the tremendous interest surrounding young people and STEM education, the role of school libraries in these initiatives is rarely examined. In this article, we outline a sociocultural approach to explore how school library programs can play a critical role in STEM education and articulate the need for research that examines the contributions of school libraries as potential hybrid spaces for STEM learning. We propose that school library programs become active participants in STEM learning through the specific roles that school librarians currently play in schools, such as information specialist, instructional partner, and technology ally. We also highlight how these roles can be tailored toward helping young people develop STEM identities.

Increasing the engagement of underrepresented minorities and females in science, technology, engineering, and math (STEM) fields is currently a critical issue facing education. Recent analysis finds that young women and young people from lower socioeconomic backgrounds are less likely

1. Assistant professor and associate director of the Information Policy and Access Center, College of Information Studies, University of Maryland, Room 4105, Hornbake Building, South Wing, College Park, MD 20742; Telephone (301) 405-3406; E-mail mmsubram@umd.edu.

2. Assistant professor, College of Information Studies, University of Maryland, Room 4105, Hornbake Building, South Wing, College Park, MD 20742; Telephone (301) 405-2037; Email juneahn@umd.edu.

3. Associate professor, College of Information Studies, University of Maryland, Room 4105, Hornbake Building, South Wing, College Park, MD 20742; Telephone (301) 405-4989; Email kfleisch@umd.edu.

4. ADVANCE professor, associate dean of research, College of Information Studies, University of Maryland, Room 4105, Hornbake Building, South Wing, College Park, MD 20742; Telephone (301) 405-7406; E-mail allisond@umiacs.umd.edu.

[Library Quarterly, vol. 82, no. 2, pp. 161-182]

(c) 2012 by The University of Chicago. All rights reserved.

0024-2519/2012/8202-0003\$10.00 
to pursue studies in STEM fields [1]. A deep engagement in STEM requires much more than memorizing isolated facts or information. Pursuing STEM interests also requires scientific literacies that are embedded in talking, reading, viewing, and doing science. A vital question to answer is how to engage underrepresented young people in STEM and help them persist in these fields as they progress through their education and professional trajectories. The problem is complex and requires the coordination of many sociocultural factors that affect young people's progress through the STEM pipeline, such as socioeconomic status, gender, cultural norms and values, ethnicity, access to information, and others.

At the national level, there are scalable initiatives that have begun taking shape in addressing the above-mentioned issue. The National Science Foundation (NSF) has been instrumental in spurring innovation of tools and capabilities that provide and maintain cyberinfrastructure to enhance STEM educators' capabilities and productivity [2]. In its Strategic Plan for Fiscal Years 2011-2016, NSF has clearly indicated its intention to invest in innovative learning tools that utilize emerging technologies developed from partnerships among scientists, educators, and engineers [2]. As a result, NSF has articulated many funding programs, such as Cyberlearning: Transforming Education, Discovery Research K-12, Transforming STEM Learning, Informal Science Education, and others.

The Obama administration also has paid significant attention to the troubling signs of American students' performance in mathematics and science, especially in response to the Programme for International Student Assessment (PISA), whereby American students ranked significantly lower in science and math literacy compared to their counterpart students in other developed countries. The most recent PISA results showed that American students ranked seventeenth out of thirty-three in science literacy and ranked twenty-fifth out of thirty-three in math literacy among students in developed countries [3]. President Obama launched the Educate to Innovate campaign, which detailed some tangible initiatives to increase STEM literacy overall and expand STEM education to underrepresented groups [4]. For example, Educate to Innovate promoted initiatives to create video games for science learning, community involvement in science teaching, and media campaigns to motivate students to pursue science.

At a micro level-for example, in schools, libraries, classrooms, and homes-research suggests that young people can engage in STEM via numerous pathways. Technology and media play a large role in the ways that young people can connect to STEM learning. For example, researchers are creating virtual worlds and games that leverage young people's interest to learn science concepts [5-7]. Foundations are creating digital labs in public libraries to teach young people media literacy skills $[8,9]$. Re- 
searchers are also beginning to find that young people engage with scientific practices via their participation in everyday digital media. For example, Constance Steinkuhler and Sean Duncan (2009) observe that World of Warcraft players exhibit numerous scientific practices, such as systems thinking, model-based reasoning, and social knowledge construction, as they collaboratively solve problems in the online game [10]. These initiatives and research programs combine to suggest that media, technology, and social networks may help connect young people's everyday interests to meaningful STEM learning.

Despite the tremendous interest and energy surrounding young people and STEM education, the role of school libraries in these initiatives is rarely examined. In this article, we outline how school library programs can play a critical role in STEM education and articulate the crucial need to examine the contributions of school libraries. If one takes seriously the need to link young people's out-of-school interests to their STEM learning, school libraries emerge as an ideal hybrid space to bridge the formal classroom with the broader world. However, much work needs to be done to define the most effective hybrid spaces, research how they could be implemented in school library settings, and evaluate their effects on students' STEM learning.

The major goal of this article is to illustrate the potential of school library media programs to serve as effective hybrid spaces to encourage STEM identity development and STEM learning and to call for more research that substantiates this assertion from a sociocultural perspective. We first introduce the issues surrounding STEM education and the calls for more effective STEM education. Second, we describe the concept of STEM identity development and its importance in increasing the engagement of underrepresented minorities and females in STEM fields [11-13]. The article outlines sociocultural theories of learning and how the framework can contribute toward STEM identity development [12, 14-16]. A sociocultural understanding of young people's interest in learning highlights the need to integrate their everyday interests with their formal STEM education. For example, media forms such as young adult fiction, nonfiction, popular science, popular movies, and television are all opportunities to connect young people's interests to science. Young people's interests in media, technology, and social networks also provide critical avenues through which students can engage in STEM [17-20]. Finally, we highlight the ways in which the school library program is the ideal place to connect young people, media, and technology to engage students in STEM. We provide concrete examples on how the expertise of school librarians can be leveraged to engage young people in STEM identity development and learning. 
The Engagement of Underrepresented Minorities and Females in STEM

Decades of educational initiatives have had little measurable effect on increasing the participation of minorities in STEM education and employment. While the need for students to excel in STEM fields grows as the country seeks to maintain its competitive edge in scientific and technological research and industry, studies both within the United States and internationally paint a troubling picture of students' STEM achievements. In addition to the PISA findings presented earlier, recent reports from the National Assessment of Education Progress [21] find that fewer than 35 percent of fourth graders and one-third of eighth graders perform at or above proficient levels in science. While these statistics reflect a slight overall improvement over the past two decades, racial achievement gaps have remained static [21]. At grades four and eight, white students had higher average scores than other racial/ethnic groups, and Asian/Pacific Islander students scored higher than black, Hispanic, and American Indian/Alaska Native students.

Recent national analysis finds that gender, socioeconomic status, and race continue to define gaps in STEM participation. Young women and those from lower socioeconomic backgrounds are less likely to pursue STEM majors in college. Furthermore, white young people are more likely to complete STEM degrees than their black or Hispanic peers [22]. An example of a STEM profession that is often highlighted in the literature as lacking the participation of women and minorities is computer science or information technology (IT). In 2008, women comprised 57 percent of the professional workforce of the United States but only 24 percent of the professional workforce in IT. The more startling news is that in 2008 only 3 percent of computer scientists were female and African American, 3 percent were female and Asian, and only 1 percent were female and Hispanic (inclusive of Latinas) [23]. Latino representation in the information technology workforce is strongest at the entry level ( 5 percent) and declines to less than 1 percent at the top level. These are alarming statistics [13], given that the Latino population is projected to increase to 30 percent of the total US population by 2015 as compared with 15 percent in 2007 [24, 25].

STEM careers are highly skewed by race, gender, and income, favoring wealthier communities in comparison to less privileged populations [26]. While the issues of STEM careers are often discussed in relation to underrepresented populations as an issue of race and ethnicity, underrepresentation of these communities in STEM must also include those who are underserved and disadvantaged. Having limited access to resources and technology also serves as a social and learning disadvantage to many young people who come from families that are in poverty or restricted to 
access due to geographic locations [27-29]. According to a recent Pew Report [30], technology and Internet access is becoming widespread across all demographic groups; however, gaps in use continue to persist. For example, recent statistics demonstrate that even with the growth in access to the Internet through cell phones by Latinos and African Americans, usage is more "entertainment than empowerment" [30]. Minority groups and those from lower socioeconomic backgrounds might utilize mobile devices and the Internet for entertainment but less for activities such as learning a specific skill, finding information, and other "empowermentlike" activities.

These patterns of use may be due to the nature of mobile devices that currently do not facilitate particular types of engagement, such as classroom-based learning, productivity applications (word processing, data analysis, etc.), or activities such as applying for a job [30]. Rather, current mobile access to the Internet appears to encourage more entertainmentbased uses, and individuals from lower socioeconomic backgrounds appear to use mobile devices as their primary access points. To fulfill both broadband access and empowering goals, such as the need to obtain information or survival type of tasks, many young people turn to school and public libraries to obtain access to the Internet $[8,31]$. It is critical to understand how to engage underrepresented young people in learning activities related to STEM in community information centers such as public and school libraries. This article emphasizes the potential of school libraries to help underrepresented young people persist in STEM fields as they progress through their education and professional trajectories.

\section{The Importance of STEM Identity Development}

As researchers examine the unique issues related to the STEM engagement of underrepresented young people, the concept of identity emerges often in the literature. A sociocultural theory of learning suggests that one's cultural history and personal experiences greatly influences how one $(a)$ engages with STEM learning and $(b)$ integrates STEM into future aspirations. How one talks about science, does science, learns about science, and aspires to pursue science is influenced by prior life experiences, social circumstances, and home life, which are inextricably related to factors such as race, gender, and socioeconomic status [12, 14-16]. Sociocultural theories of learning have highlighted how identity is a key factor in the STEM success of poor, minority, or female young people. For example, researchers have observed how African American young people bring their own life experiences and social identities to science programs. Some young people bring personal identities that conflict with their participation in 
science, while others develop identities that include science as a possible future [12]. Studies of young women find that they develop different identities as scientists that are influenced by their relationships in and outside of school [14, 32].

Defining identity as it relates to STEM learning is complex. Young people bring knowledge or past experiences to new learning environments such as a science classroom. Nancy Brickhouse and Jennifer Potter's [14] study of two young women, Ruby and Crystal, as they progressed from middle school through high school, highlights how these young women's life experiences affected their success in a vocational computer program. Ruby began in seventh grade as a low achiever in science but through the years succeeded in the demanding computer track. Crystal began the study as a high academic achiever but ultimately failed in the computer program. The researchers observed that Crystal's isolating experience of being the only African American student in her honors science classes and her lack of computer experience at home contributed to her developing an identity as not enjoying computer science.

Conversely, Ruby did not particularly like science or computers. However, the pervasive presence of a computer in her home, and her father's own interest and work with computer hardware, influenced her acceptance of computing as an academic and career path. Similarly, Kathleen Burnett, Mega Subramaniam, and Amelia Gibson [33] found that Latinas who held senior positions in STEM careers described critical experiences during their youth in which they received positive support from peers, family, or other members of their social network that solidified their determination to continue their pursuit of a technical career despite a more general perception of negative gender and social typing. Numerous ethnographic and qualitative studies have highlighted similar experiences of underrepresented young people [12].

The emerging picture is that young people bring their own wealth of experiences to new science learning environments. Learning environments, such as a science classroom, require different sets of content knowledge, social norms, and cultural expectations. Thus, young people's own identities merge, and sometimes conflict with, formal science settings to create hybrid spaces [34]. Prior research suggests that successful hybrid spaces help students link formal STEM learning with their existing experiences. For example, teaching young people in their everyday language, then linking these discussions to formal scientific vocabulary, has been related to better learning performance [35, 36]. Another strategy suggested by researchers has been to include socioscientific issues (SSI) into science curricula [37]. For example, students might discuss the moral and ethical dilemmas of cloning and in doing so need to learn and utilize knowledge about genetics into their arguments. This merging of values, identity, and 
scientific argumentation may serve as a way to deeply engage young people in STEM. An SSI approach also links to the idea of hybrid spaces, as they provide ways to connect a student's prior knowledge, values, and experiences to the formal practice of scientific thinking.

Finally, young people's participation in reading and in media and technology also create hybrid spaces that may help them engage with science. The process of reading and creating narratives around science can potentially be a major component in the development of STEM identities [38, 39]. For example, reading or writing science fiction (also known as speculative fiction) via other media may significantly impact how young people think about and view their world [40]. Engaging in both science fiction and popular science may influence young people's understanding of and attitudes toward science [41, 42]. Science fiction has been shown to have significant potential for structuring and changing individuals' lives [43, 44 ], including potentially encouraging young people to pursue STEM careers [45-47].

Today's young people not only consume media such as science fiction books, television, or film but also participate as creators of media. With recent developments in social technologies such as blogs, social network sites, and virtual worlds, young people are able to create rich content that they share with the world. Studies of young people's interest in learning with media find that they use technologies such as social network sites to write extensively, explore their interests, create videos, develop virtual characters, and collaborate with others [17, 48, 49]. When young people participate in online communities, multiplayer games such as World of Warcraft, or social network sites, they participate in different modes of learning. Researchers have found that young people develop their personal identities, share knowledge or information with peers, and collaboratively solve problems with their networks $[10,50,51]$. These literacy practices are not only salient in social contexts but also are vital practices of science communities. Thus, new media tools such as online communities and networks might be leveraged to create ideal hybrid spaces where students can connect their personal interests and identities to STEM learning activities.

School Libraries as the Ideal Hybrid Space for STEM Learning

Numerous initiatives are currently underway to design technologies and learning programs for STEM learning. Digital hubs in public libraries, virtual worlds and video games, and after-school programs are just some of the ways that educators and researchers attempt to reach young people. Since the 1960s, the affects of school library media programs on student learning have been the subject of discussion. The body of literature on 
school library programs has found a consistently positive and significant correlation between school library resources and student achievement in the United States [52-55]. The majority of these studies showed a correlation between the school library media programs that are offered and the improvement of reading and language arts scores in student but has never attempted to demonstrate a relationship to mathematics or science learning. However, with the recent introduction of the Common Core State Standards Initiative for mathematics, which provides a consistent and clear understanding of what students are expected to learn in mathematics across the nation [56], we anticipate that school library media and education researchers will soon map the contribution of school library media programs to mathematics learning.

We argue that school library programs are, in fact, an ideal setting to create a successful hybrid space for young people to engage in STEM and provide promising bridging or scaffolding spaces for STEM learning. School libraries often serve as the hubs of different media forms: books, periodicals, videos, computers, and the Internet. Library settings are places for student exploration and discovery, and are usually not tied to the negative stereotypes students may have of the formal classroom. Students might not enjoy math or science class, but they may still utilize the library to read books, watch videos, or log in to their computer networks.

The learning environment that can be created in a school library may also represent a starkly different context compared to the formal classrooms present in the same school. For example, education researchers consistently find numerous constraints that hinder new innovations in teaching and learning within the formal classroom [57, 58]. For example, K-12 teachers face obstacles such as heightened pressures to adhere to curricular standards and high-stakes testing requirements that may hinder their inclination to experiment with new methods and techniques. In addition, the lack of teacher knowledge about technology-enhanced learning and how to engage students with different media contributes to the lack of technological and pedagogical innovation seen in K-12 classrooms [59]. Finally, there is consistent concern that K-12 schools that serve the most underrepresented students, such as those from lower socioeconomic status groups, may promote the most impoverished forms of learning with technology. Underserved students might use technology for mundane and typical tasks such as drill-and-kill activities or teacher lectures, while their more privileged peers attend schools that experiment with new forms of media and technology [60].

While there are numerous obstacles to implementing new teaching techniques, learning technologies, and strategies to promote STEM engagement in formal classrooms, school library settings offer a uniquely different space that might foster new innovations. School library media centers are 
often the hub of technology and information resources for students. In addition, these spaces are often less tied to the pressures faced in formal classrooms, such as the need to adhere to standardized tests or requirements. Finally, school librarians may also be the key change agents to develop and implement media-enhanced education because they are $(a)$ often leaders of media programs in schools, $(b)$ best equipped to spread an educational program through their existing collaboration with teachers across an entire school, and $(c)$ able to connect young people to resources that bridge in and out of school contexts.

Despite these unique characteristics of school libraries and librarians, there has been little discussion about utilizing these resources to promote STEM learning and innovation. There is a tremendous opportunity to both communicate the potential ways that school libraries can promote innovation in STEM education and develop research that collects evidence of these innovations. School librarians have only recently begun voicing their potential roles in enhancing STEM learning [61-66]. Most research in school librarianship and STEM learning has been centered on building digital resources for STEM learning [64, 65, 67-69] and site-based sharing of STEM programs in school libraries by school librarians themselves [65, 70]. This early work has not focused on the effects of school library media programs on science, math, and/or computer science learning.

We envision several opportunities to implement and research STEM learning in school library settings. First, young people can work with librarians in their schools to consider the science embedded in print and nonprint sources such as books, magazines, news sources, television, movies, their classrooms, and other sources. Science is embedded in almost every aspect of the world. For example, science fiction novels may incorporate ideas about future technologies. Popular films such as The Matrix are built from concepts of artificial intelligence and computer science. Documentaries about the environment may spur connections to biology and the ecosystem. The study of art and color might connect to learning about light waves.

In formal STEM classrooms, much emphasis is placed on facts and information. However, a deeper consideration of what it means to engage with STEM reveals that the disciplines are fundamentally a way of viewing the world [71]. Young people need guidance to link what already interests them about their world to science or to see what is around them through the lens of science. There are tremendous opportunities for school library programs to promote these types of connections. Similarly, systematic research is needed on the broader impacts of science-infused media on young adults' emerging views of science, socioscientific issues, and STEM concepts.

Second, school libraries have the unique ability to infuse technology and 
new media into the STEM learning process. Students experience constraints or are discouraged by technology policy in schools that defers or blocks such media-based participation [20, 72, 73]. In addition, recent national data reveal that there is a significant digital disconnect between young people's aspirations about the use of technology-enhanced learning and the values and aspirations of their less technology-comfortable teachers and administrators $[20,74]$. Outside of school, the majority of high school (72 percent) and middle school (65 percent) young people communicate with others via instant messaging (IM), e-mail, or text messaging. Of special significance, outside of school, 51 percent of middle school young people and 59 percent of high school young people report their primary vehicle for communicating with their friends online is through social network sites (SNS) such as Facebook and MySpace [20].

While formal science classrooms may be constrained in their use of technology, school libraries can promote youth participation in technology and online communities that may enhance their STEM learning. The Speak Up 2009 data suggest that school librarians are typically the most digitally literate staff members in a school. In addition, they are more likely than teachers to communicate and collaborate via SNS or digital media tools [20]. For young people, the incorporation of books, media, and technology are merely a natural extension of the way they are currently living and learning outside of schools. These students also perceive that school librarians share the same motivations and values toward technologies. Thus, there exists opportunities to leverage school librarians' expertise in technology, literacy, information resources, and the school's curriculum to help students connect their formal learning to their everyday interests. Such initiatives may increase the relevancy of a student's learning experience and begin to close the persistent digital disconnect by using school library media programs as effective hybrid spaces for STEM learning.

The Model School Library Media Program That Encourages STEM Identity Development

Very few studies to date have examined the evolving roles of school librarians and library programs for STEM learning [20]. However, there is increasing interest from school librarians in playing a more integral role in students' STEM education [63, 65, 74-76]. In this section, we describe the roles that school librarians currently play in schools and how these roles can be tailored toward helping young people develop STEM identities by leveraging two existing interests of young people that remain isolated from science learning: (1) interests in reading science-infused books and 
watching science programs and (2) interests in media, technology, and social networks.

\section{The School Librarian as Information Specialist}

With the introduction of Information Power standards for effective school library programs in 1998 [77], school librarians have shifted their focus from the traditional roles that are often associated with librarians (such as the teacher of library skills and maintainer of collections) to playing a substantial role as the information specialist, teacher, program administrator, and instructional partner to teachers in schools [78, 79]. As an information specialist, the school librarian provides leadership in selection, acquisition, evaluation, and organization of information resources and technologies in all formats and has expertise in the ethical use of information [80, 81]. School librarians have a great understanding of their collection and often purchase books based on the needs of the curriculum, the students, and the staff of the school. As one of the few personnel in school who are responsible for all students, school librarians often manage the ecosystem of media resources available to young people, including books and periodicals in various formats, media, and technology tools.

Students who describe themselves as hating science when they were in school actually do have inclinations toward science. However, this interest does not come in the form of dreaded exams, dull classes, or heavy textbooks [82]. Young people might grow up to become people who enjoy a good medical story, follow the space program, visit zoos, build their own computers, or seek a rare herb through their own investigations $[82,83]$. In traditional classroom settings, these explorations are often not considered "science." Rick Roche observes that "without cognition of the discipline [science], they [actually] surround themselves with science" [82, p. 143]. School librarians may be best positioned to direct young people with such interests in science to materials that may spur their engagement. Most important, school librarians are already trained to provide reader advisory information and select appropriate materials based on the reading level, literacy, special needs, and interest level of these young people.

School libraries normally carry collections of popular science, and school librarians can provide reader advisory information for young people who have varied interest in science and levels of interest in science. These resources can be in the form of print books (such as A Short History of Nearly Everything by Bill Bryson and You Call This the Future? The Greatest Inventions Sci-Fi Imagined and Science Promised by Nick Sagan, Mary Frary, and Andy Walker), magazines (such as National Geographic and Scientific American), television programs and movies (such as PBS's Nature or NOVA and the History Channel's Engineering an Empire), graphic novels (such as T-Minus: The Race to the Moon and Bone Sharps, Cowboys, and Thunder Lizards 
by Jim Ottaviani), and podcasts (such as TED Talks and NPR's Climate Connections podcast) [82]. This list is not comprehensive, as there are popular science materials for nearly every taste and aspects of science.

Young people can also "connect" to certain characters portrayed in popular sciences, such as the characters of contemporary scientists as recounted in Einstein: His Life and Universe by Walter Isaacson and The Remarkable Life of William Beebe: Explorer and Naturalist by Carol Gould, or characters of science pioneers such as The Curies: A Biography of the Most Controversial Family in Science by Denis Brian and Google Boys by A\&E cable TV network, or controversial figures in science such as Freud: Inventor of the Modern Mind by Peter Kramer and Tesla, Master of Lightning by PBS [82]. Such "connection" with these scientists and the science involving them could motivate young people to begin developing their STEM identities.

Science fiction is considered to be the genre of the future, driven by the "what if . ..," "if only ...," "if this goes on ...?" questions, and thrives on new and provocative ideas relating to STEM [84]. Science fiction already has a strong presence in various media, from movies to television, to traditional books and graphic novels, to computer and video games, and young people may be just as likely to watch science fiction as read or interact with it. Jessica Moyer, Christy Donaldson, and Casie Wagner [85] theorize that many science fiction collections assume that readers have background knowledge in math and science, which requires the librarian to be conscious in selecting and recommending appropriate materials for young people.

These science fiction resources can be in the form of print books (such as Ender's Game, Neuromancer, and Dawn), graphic novels and manga (such as Ghost in the Shell), movies (such as Avatar and Star Wars), television shows (such as Battlestar Galactica, Firefly, and Star Trek), and computer and video games (such as Halo, which inspired a series of Halo books), all of which are becoming increasingly interconnected [85]. Young people can also "connect" to certain characters portrayed in science fictions, such as the characters of leaders in Admiral Adama in Battlestar Galactica, Mal in Firefly, and female heroines who can certainly increase the interest of girls in science, such as Princess Leia in Star Wars and Major Motoko Kusanagi in Ghost in the Shell [85]. In addition, school librarians can also connect students to female heroines from underrepresented groups, such as Nyota Uhura in Star Trek and Lilith Iyapo in Dawn. Such "connection" with these characters can boost girls' confidence in pursuing STEM identities and help them to visualize and comprehend their potential futures in sciencebased careers. 


\section{The School Librarian as the Instructional Partner across the Curriculum}

The most important role of a school librarian (and unfortunately the least known role) is the role of instructional partner [78, 80, 81]. A school librarian's role as an instructional partner has further morphed to include teaching and integrating multiple literacies across the curriculum [78, 8688], such as information, digital, technology, media, and visual literacies, to students with the introduction of Standards for the 21st-Century Learner in 2007 [80, 81]. The new standards broaden the concept of literacy by "incorporating the skills necessary for a more constructivist view of learning, in which students are empowered to ask meaningful questions and follow a path of discovery to construct their own understandings, draw conclusions, create new knowledge, and share their knowledge with others" [89, p. 50].

In this role as an instructional partner, the school librarian collaborates or partners with classroom and STEM subject teachers to teach and integrate different literacy practices into the curriculum. School librarians also build connections between student information/research needs, curriculum content, learning outcomes, and information resources as they support the overall educational community in the school [55, 80, 81]. School librarians are also tasked to infuse the standards, skills, dispositions, and responsibilities detailed in the Standards for the 21st-Century Learner across all subjects and curricula. Gail Bush [90] characterizes the school library as a learning laboratory, where "the hard lines between and among disciplines and subjects within disciplines soften as all knowledge has a place in this physical, virtual, and intellectual space" [90, p. 24].

School librarians are able to tap into resources across the entire curriculum and connect the interrelationships between subjects in schools. Through these strategies, they are able to ensure that students are able to make these linkages as well. School librarians are expected to be aware of curriculum offerings of every subject in schools. If needed, they can map the relationships of other subject content areas to STEM learning in discussions with STEM teachers and can initiate collaborative projects among multiple subject areas using resources and services available in the school library.

In recent studies, school librarians are demonstrating these evolving roles as curricular partners who connect resources to formal STEM learning. For example, in an ongoing study at the University of Maryland [91], researchers are examining the science content in popular science fiction and aligning it with the Maryland Voluntary State Curriculum. The study participants highlighted science concepts in young adult literature such as Life as We Knew It by Susan Beth Pfeffer. This best-selling, young adult novel tells the story of Miranda and her family as they face a climate crisis 
after the moon's orbit is altered by an asteroid. The fast-paced story is interwoven with explanations of how the tilt of the Earth's axis affects climate, the role of gravity in tides, and the global affects of volcanic eruptions-all items under Standard 2.0 Earth/Space Science on the Maryland State Science Curriculum for Grade 8.

Similarly, Scott Westerfeld's highly popular Leviathan series (which was ranked thirty-eighth on Amazon for its graphic novel incarnation at the time this article was written) postulates an alternate history of World War I in which the Darwinists (the English) use their knowledge of genetics to develop specialized animals for use in flight, weapons, transport, and communications. The Klankers (the Germans) use their knowledge of engineering to develop similar technologies using metal. In the process, students are exposed to ideas around the Standard 3.0 Life Science for Grades $6-8$, including the concepts of selective breeding and adaptation, and the Standard 5.0 Physics for Grade 8, with multiple scenes hinging on the properties of force and motion. These examples are ways that librarians can connect popular interests to the science curriculum and motivate high levels of collaboration among STEM teachers, other subject matter teachers, and school librarians that will result in young people seeing connections of science to other disciplines. The school library can connect young people to science through print, media, and online communities in a way that is freed from the formal identities and stigmas attached to the academic classroom.

Teachers are often reluctant to collaborate with school librarians due to many factors, including the pressure of high-stakes and standardized testing, the culture of K-12 schools, and a misconception of collaboration practices being time consuming [86, 92]. In the past, school librarians often struggled to gain recognition from teachers about the importance of process or literacy skills for learning any content [89]. Despite these challenges, school librarians have shared many successful examples of coplanning, coteaching, and coassessing with language arts and other social science-related curricula [66, 87, 92-94]. In STEM curriculum areas, collaborations are less frequently attempted due to the same misconception of collaboration mentioned above, and there are calls for more collaboration between STEM teachers and school librarians [63, 65, 66, 95]. We propose that STEM teachers leverage school librarians' capabilities in tapping into other curricula and providing resources and technology tools for science discoveries.

\section{School Librarians as Technology Allies}

A final role that is underexplored in the literature is the potential for school librarians to be technology allies in their institutions. As mentioned earlier, numerous constraints hinder the ability of K-12 schools to deeply 
integrate new media tools into the curriculum [58, 96]. Daily scheduling, lack of planning time, teacher knowledge, and professional development are all limitations that contribute to the lack of technology use by teachers in classrooms [58, 59]. In contrast, school librarians are utilizing emerging technologies in many of the same ways as young people. As mentioned before, the Speak Up 2009 data suggest school librarians are more likely than teachers to communicate and collaborate via SNS or digital media tools [20]. With these experiences come unique opportunities for school librarians to become active change agents in their school communities. A few areas that offer potential avenues for innovation include having a voice in education policy, teacher training, and curricular integration for students.

School policies may hinder student access to potential learning technologies, but school librarians with technological experience can have an influence in changing these policies. For example, June Ahn, Lauren Bivona, and Jeff DiScala (2011) find that many US school districts have illformed policies on students' social media access due to a lack of experience and understanding of the learning potential of these tools [73]. School librarians can play a vital role in educating administrators and fellow teachers on the potential positive uses of social technologies, online communities, and virtual worlds to enhance STEM learning. In addition, school librarians have a unique opportunity to help shape and develop education policies to broaden student access to new media tools.

Another area in which school librarians can provide a voice is through training and modeling innovative technology-enhanced practices to their fellow teachers. Lack of teacher knowledge about how to effectively integrate new media tools into the curriculum is a major factor for the lack of innovation in classrooms [59]. School librarians, through their work as instructional partners with teachers, have a ripe opportunity to model new teaching strategies, integrate educational technology, and advocate for exciting change in their schools. Prior education research suggests that teachers adopt technology more effectively from observing and talking with their peers $[97,98]$. School librarians may be the best suited to act as these peer mentors to diffuse new innovations throughout their school organizations.

Finally, school librarians can be effective allies in helping young people connect their engagement with technology and the Internet with their learning in school. School libraries can be structured to be an ideal hybrid space for them to translate their interest in media and technology to STEM learning. The presence of online communities and powerful tools, such as social network sites, virtual worlds, and video games, now afford the opportunity to explore how such a hybrid space can be designed to help young people safely bridge the boundaries between their personal and 
science-learner identities. School library professionals have the unique opportunity to experiment and champion the use of new media tools to deeply engage students in STEM areas. Such future work will require the careful balance of multiple factors including knowledge of the curriculum, new trends in technology, and how those trends might come into conflict with existing school policies or classroom practices.

\section{Conclusion and Recommendations}

In this article, we consider the critical issue of STEM participation by underrepresented student groups. We also used a sociocultural perspective to show that learning science is deeply embedded in a variety of life experiences that extend beyond the classroom. A STEM identity is developed by active participation in the environment. Libraries are ideal places to promote such identities because they are uniquely situated as a hub between the outside world and the classroom, between multiple media forms and technologies, and between personal and formal learning. It is imperative to explore how young people may develop higher levels of participation in science and a sense of their capability to pursue science as products of their participation in the model school library media program described above.

We have proposed the conceptual idea of leveraging young people' interests in reading science-infused books and watching science programs aalong with their interests in media, technology, and social networks to encourage the development of STEM identities. We propose the active participation of the school library media program toward the development of STEM identities among young people by having school librarians (1) provide advisory information on the science-infused books and programs that young people can read-the school librarian as the information specialist; (2) collaborate with STEM teachers and provide intellectual and physical access that further enrichs the STEM learning-the school librarian as the instructional partner; and (3) act as technology allies to help educators and students experiment with new media tools and online communities.

Future research is needed to understand how best to connect young people to library resources around STEM content areas. The relevant questions around implementation include understanding how librarians can collaborate with STEM teachers, connect with students on a personal level to recommend the most effective means to engage them in science, and create learning programs in the library that explicitly connect the creative activities of the library to formal STEM concepts. There is a growing need for school library professionals to define their roles in promoting STEM 
education. Such distinct involvement of school librarians with high-stake areas such as STEM may potentially educate administrators and education experts on the value of having school librarians in their school districts and halt the widespread layoffs currently faced by school librarians. Simultaneously, researchers in library and information sciences, education, and STEM learning have a unique opportunity to evaluate such efforts on students' success and report the impacts of school library media programs on STEM learning.

\section{REFERENCES}

1. National Research Council, Committee on a Conceptual Framework for New K-12 Science Education Standards, Board on Science Education, Division of Behavioral and Social Sciences and Education. A Framework for K-12 Science Education: Practices, Crosscutting Concepts, and Core Ideas. Washington, DC: National Academies Press, 2011.

2. National Science Foundation. Empowering the Nation through Discovery and Innovation: NSF Strategic Plan for Fiscal Years 2011-2016. NSF11-047. Arlington, VA: National Science Foundation, 2011. http://www.nsf.gov/news/strategicplan/nsfstrategicplan_2011_2016.pdf.

3. Fleischman, Howard L.; Hopstock, Paul J.; Pelczar, Marisa P.; and Shelley, Brooke E. Highlights from PISA 2009: Performance of U.S. 15-Year-Old Students in Reading, Mathematics, and Science Literacy in an International Context. NCES 2011-004. US Department of Education, National Center for Education Statistics. Washington, DC: Government Printing Office, 2010.

4. The White House. "President Obama Launches 'Educate to Innovate' Campaigns for Excellence in Science, Technology, Engineering and Math (STEM) Education." Office of the Press Secretary, White House, Washington, DC, 2009. http://www.whitehouse.gov/thepress-office/president-obama-launches-educate-innovate-campaign-excellence-sciencetechnology-en.

5. Dede, Chris. "Immersive Interfaces for Engagement and Learning." Science 323 (2009): 66-69.

6. Neulight, Nina; Kafai, Yasmin B.; Kao, Linda; Foley, Brian; and Galas, Cathleen. "Children's Participation in a Virtual Epidemic in the Science Classroom: Making Connections to Natural Infectious Diseases." Journal of Science Education and Technology 16, no. 1 (2007): $47-58$.

7. Ondrejka, Cory. "Education Unleashed: Participatory Culture, Education, and Innovation in Second Life." In The Ecology of Games: Connecting Youth, Games, and Learning, edited by Katie Salen, pp. 229-52. Cambridge, MA: MIT Press, 2008.

8. Institute of Museum and Library Services. Museums and Libraries Engaging America's Youth: Final Report of a Study of IMLS Youth Programs, 1998-2003, edited by Judy Koke and Lynn Dierking. Washington, DC: Institute of Museum and Library Services, 2007. http:// www.imls.gov/assets/1/AssetManager/YouthReport.pdf.

9. Institute of Museum and Library Services. About Us: Partnerships MacArthur-IMLS Learning Labs Project. Washington, DC: Institute of Museum and Library Services, 2011. http:// www.imls.gov/about/macarthur.shtm.

10. Steinkuhler, Constance, and Duncan, Sean. "Scientific Habits of Mind in Virtual Worlds." Journal of Science Education and Technology 17, no. 6 (2009): 530-43.

11. Cohoon, J. McGrath, and Aspray, William, eds. Women and Information Technology: Research on Underrepresentation. Cambridge, MA: MIT Press, 2006. 
12. Polman, Joseph L., and Miller, Diane. "Changing Stories: Trajectories of Identification among African American Youth in a Science Outreach Apprenticeship." American Educational Research Journal 47, no. 4 (2010): 879-918.

13. Klawe, Maria; Whitney, Telle; and Simard, Caroline. "Women in Computing-Take 2." Communications of the ACM 52, no. 2 (2009): 68-76.

14. Brickhouse, Nancy W., and Potter, Jennifer T. "Young Women's Scientific Identity Formation in an Urban Context." Journal of Research in Science Teaching 38, no. 8 (2001): 96580.

15. Kozoll, Richard H., and Osborne, Margery D. "Finding Meaning in Science: Lifeworld, Identity, and Self." Science Education 88, no. 2 (2004): 157-81.

16. Lemke, J. L. "Articulating Communities: Sociocultural Perspectives on Science Education." Journal of Research in Science Teaching 38, no. 3 (2001): 296-316.

17. Ito, Mizuko; Baumer, Sonja; Bittanti, Matteo; Boyd, Danah; Cody, Rachel; Herr-Stephenson, Becky; Horst, Heather A.; et al. Hanging Out, Messing Around, and Geeking Out: Kids Living and Learning with New Media. Cambridge, MA: MIT Press, 2009.

18. Johnson, Larry; Smith, Rachel; Levine, Alan; and Haywood, K. The 2010 Horizon Report: K-12 Edition. Austin, TX: New Media Consortium, 2010.

19. Henry J. Kaiser Family Foundation. Generation M2: Media in the Lives of 8- to 18-Year Olds. http://www.kff.org/entmedia/upload/8010.pdf.

20. Project Tomorrow. Creating Our Future: Students Speak Up about Their Vision for 21stCentury Learning. 2010. http://www.tomorrow.org/speakup/pdfs/SU09NationalFindings Students\&Parents.pdf.

21. U.S. Department of Education. National Assessment of Education Progress-Science Report Card. Washington, DC: US Department of Education, Institute of Education Sciences, National Center for Education Statistics, 2009.

22. U.S. Department of Education. Students Who Study Science, Technology, Engineering, and Mathematics (STEM) in Postsecondary Education. Washington, DC: US Department of Education, Institute of Education Sciences, National Center for Education Statistics, 2009.

23. National Center for Women in Information Technology (NWCIT). Women and Information Technology: By the Numbers. 2009. http://www.ncwit.org/pdf/BytheNumbers09.pdf.

24. Dowd, Alicia C., Malcom, Lindsey E., and Bensimon, Estela Mara. Benchmarking the Success of Latina and Latino Students in STEM to Achieve National Graduation Goals. Los Angeles, CA: Center for Urban Education, University of Southern California, 2009.

25. Passel, Jeffrey S., and Cohn, D'Vera. A Portrait of Unauthorized Immigrants in the United States. Washington, DC: Pew Research Center, 2009. http://pewhispanic.org/files/ reports/107.pdf.

26. Zarrett, Nicole; Malanchuk, Oksana; Davis-Kean, Pamela E.; and Eccles, Jacquelynne. "Examining the Gender Gap in IT by Race: Young Adults' Decisions to Pursue an IT Career." In Women and Information Technology: Research on Underrepresentation, edited by J. McGrath Cohoon and William Aspray, pp. 55-88. Cambridge, MA: MIT Press, 2006.

27. Jaeger, Paul T.; Subramaniam, Mega; Jones, Cassandra B.; and Bertot, John Carlo. 2011. "Diversity and LIS Education: Inclusion and the Age of Information." Journal of Education for Library and Information Science 52 (2): 166-83.

28. Norris, Pippa. Digital Divide: Civic Engagement, Information Poverty and the Internet Worldwide. Cambridge: Cambridge University Press, 2001.

29. Vie, Stephanie. "Digital Divide 2.0: 'Generation M' and Online Social Networking Sites in the Composition Classroom." Computers and Composition 25, no. 1 (2008): 9-23.

30. Washington, Jesse. "For Minorities, New 'Digital Divide' Seen." Report. Pew Internet and American Life Project, 2011. http://pewinternet.org/Media-Mentions/2011/Forminorities-new-digital-divide-seen.aspx.

31. Farrelly, M. G. "Refuge in the Library." Public Libraries 48, no. 4 (2009): 24-26. 
32. Carlone, Heidi B., and Johnson, Angela. "Understanding the Science Experiences of Successful Women of Color: Science Identity as an Analytic Lens." Journal of Research in Science Teaching 44, no. 8 (2007): 1187-1218.

33. Burnett, Kathleen; Subramaniam, Mega; and Gibson, Amelia. "Latinas Cross the IT Border: Understanding Gender as a Boundary Object netween Information Worlds." First Monday 14, no. 9 (2009). http://firstmonday.org/htbin/cgiwrap/bin/ojs/index.php/fm/ article/view/2581/2286.

34. Barton, Angela Calabrese; Tan, Edna; and Rivet, Ann. "Creating Hybrid Spaces for Engaging School Science among Urban Middle School Girls." American Educational Research Journal 45, no. 1 (2008): 68-103.

35. Brown, Bryan A. "Discursive Identity: Assimilation into the Culture of Science and Its Implications for Minority Youth." Journal of Research in Science Teaching 41, no. 8 (2004): 810-34.

36. Brown, Bryan A., and Ryoo, Kihyun. "Teaching Science as a Language: A 'Content First' Approach to Science Teaching." Journal of Research in Science Teaching 45, no. 5 (2008): 529-53.

37. Sadler, Troy D.; Barab, Sasha A.; and Scott, Brianna. "What Do Students Gain by Engaging in Socioscientific Inquiry?” Research in Science Education 37, no. 4 (2007): 371-91.

38. Kilby-Goodwin, Kristi. "Putting the 'Science' in 'Science Fiction.'" Science Teacher (2010): 60-63.

39. Negrete, Aquiles. "Fact via Fiction: Stories That Communicate Science." In Pantaneto Forum 12 (2003). http://www.pantaneto.co.uk/issue12/negrete.htm.

40. Mosco, Vincent. The Digital Sublime: Myth, Power, and Cyberspace. Cambridge, MA: MIT Press, 2004.

41. Chaloner, Penny A. "Chemistry in TV Science Fiction: Star Trek and Dr. Who." In Chemistry and Science Fiction, edited by Jack H. Stocker, pp. 173-201. Washington, DC: American Chemical Society, 1998.

42. Claessens, Michel. "Science Fiction: Intuition and Fantasy." RTD Info: Magazine for European Research Special Issue, special issue (2004): 21-23.

43. Bacon-Smith, Camille. Science Fiction Culture. Philadelphia: University of Pennsylvania Press, 2000.

44. Jenkins, Henry. Textual Poachers: Television Fans and Participatory Culture. New York: Routledge, 1992.

45. Fleischmann, Kenneth R., and Templeton, Thomas Clay. "Past Futures and Technoscientific Innovation: The Mutual Shaping of Science Fiction and Science Fact." Proceedings of the 71st Annual Meeting of the American Society for Information Science and Technology. Columbus, OH: American Society for Information Science and Technology, 2008.

46. Fleischmann, Kenneth R., and Templeton, Thomas Clay. "Science Fiction in the Lives of Scientists and Engineers." In Proceedings of Digital Humanities. College Park, MD: National Science Foundation, 2009.

47. Murphy, Clarence J.; Mogus, Mary Ann; and Crotty, Patricia M. "Using Science Fiction to Help Teach Science: A Survey of Chemists and Physicists." In Chemistry and Science Fiction, edited by Jack H. Stocker, pp. 241-50. Washington, DC: American Chemical Society, 1998.

48. Jenkins, Henry; Clinton, Katie; Purushotma, Ravi; Robison, Alice J.; and Weigel, Margaret. Confronting the Challenges of Participatory Culture: Media Education for the $21^{\text {st }}$ Century. Washington, DC: MacArthur Foundation, 2006. http://digitallearning.macfound.org/atf/cf/ \%7B7E45C7E0-A3E0-4B89-AC9C-E807E1B0AE4E\%7D/JENKINS_WHITE_PAPER.PDF.

49. Lunsford, Andrea A. "Our Semi-literate Youth? Not So Fast." Report. Stanford University, n.d. http://www.stanford.edu/group/ssw/cgi-bin/materials/OPED_Our_SemiLiterate_Youth.pdf. 
50. Greenhow, C., and Robelia, Elizabeth. "Informal Learning and Identity Formation in Online Social Networks.” Learning, Media and Technology 34, no. 2 (2009): 119-40.

51. Greenhow, C., and Robelia, Elizabeth. "Old Communication, New Literacies: Social Network Sites as Social Learning Resources." Journal of Computer-Mediated Communication 14 (2009): 1130-61.

52. Callison, Daniel. "Enough Already? Blazing New Trails for School Library Research: An Interview with Keith Curry Lance, Director, Library Research Service, Colorado State Library and University of Denver." American Association of School Librarians, a division of American Library Association, 2005. http://www.ala.org/ala/mgrps/divs/ aasl/aaslpubsandjournals/slmrb/editorschoiceb/lance/interviewlance.cfm.

53. Francis, B., and Lance, K. C. "The Impact of Library Media Specialists on Students and How It Is Valued by Administrators and Teachers: Findings from the Latest Studies in Colorado and Idaho." TechTrends 55, no. 4 (2011): 63-70.

54. Library Research Service. "School Library Impact Studies." Report. Library Research Service, 2011. http://www.lrs.org/impact.php.

55. Scholastic Research Foundation. "School Libraries Work!" Report. Scholastic, 2008. http://www2.scholastic.com/content/collateral_resources/pdf/s/slw3_2008.pdf.

56. Common Core State Standards Initiative. "Common Core State Standards." Report, 2000. http://www.corestandards.org/.

57. Cuban, Larry. Teachers and Machines: The Classroom Use of Technology since 1920. New York: Teachers College Press, 1986.

58. Cuban, Larry; Kirkpatrick, Heather; and Peck, Craig. "High Access and Low Use of Technologies in High School Classrooms: Explaining an Apparent Paradox." American Educational Research Journal 38, no. 4 (2001): 813-34.

59. Wallace, Raven McCrory. "A Framework for Understanding Teaching with the Internet." American Educational Research Journal 41, no. 2 (2004): 447-88.

60. Warschauer, Mark, and Matuchniak, Tina. "New Technology and Digital Worlds: Analyzing Evidence of Equity in Access, Use, and Outcomes." Review of Research in Education 34, no. 1 (2010): 179-225.

61. Balack, Lauren. "STEM to Grow in Libraries." School Library Journal 55, no. 9 (2009): 1314.

62. Fries-Gaither, Jessica. "Beyond Penguins and Polar Bears: Bringing the Polar Regions Closer to Home." Knowledge Quest 39, no. 2 (2010): 34-38.

63. Mardis, Marcia, and Howe, Kaye. "STEM for Our Students: Content to Co-Conspiracy?" Knowledge Quest 39, no. 2 (2010): 8-11.

64. McIlvain, Eileen. "NSDL as a Teacher Empower Point." Knowledge Quest 39, no. 2 (2010): 54-63.

65. Pandora, Cherie. "STEM—How Libraries Provide STEM Information." Ohio Media Spectrum 61, no. 1 (2009): 23-27.

66. Schultz-Jones, Barbara. "School Librarians, Teachers and Optimal STEM Learning Environments." Knowledge Quest 39, no. 2 (2010): 12-18.

67. Mardis, Marcia A. "Science Teacher and School Library Media Specialist Roles: Mutually Reinforcing Perspectives as Defined by National Guidelines." In Educational Media and Technology Yearbook 2006. Westport, CT: Libraries Unlimited, 2006.

68. Mardis, Marcia A. "Children's Questions about Science: Preliminary Results of an Analysis of Digital Library Reference Questions.” Proceedings of the 71st ASISE'T Annual Meeting: People Transforming Information-Information Transforming People. Columbus, OH: American Society for Information Science and Technology, 2008.

69. Mardis, Marcia, and Hoffman, Ellen. "Collections and Connections: Science Content in Michigan Middle School Libraries.” School Library Media Research 10 (2007). http:// 
www.ala.org/ala/mgrps/divs/aasl/aaslpubsandjournals/slmrb/slmrcontents/volume10/ mardis_collectionandcollaboration.cfm.

70. Duff, Mariana Leigh. "Supporting STEM Studies in Secondary Public School Libraries." Report. San Jose State University, 2010. http://www.lausd.net/Young_Oak _Kim_Academy/YOKA/Resources_files/STEM\%20Libraries.pdf.

71. Ford, Michael J., and Forman, Ellice A. "Redefining Disciplinary Learning in Classroom Contexts." Review of Research in Education 30 (2006): 1-32.

72. Lemke, Cheryl; Coughlin, Ed; Garcia, Lauren; Reifsneider, Daren; and Baas, Jessica. Leadership for Web 2.0 in Education: Promise and Reality. Culver City, CA: Metiri Group, 2009.

73. Ahn, June; Bivona, Lauren K.; and DiScala, Jeff. "Social Media Access in K-12 Schools: Intractable Policy Controversies in an Evolving World." Paper presented at the 74th annual meeting of the American Society for Information Science and Technology, New Orleans, LA, 2011.

74. Smith, Laurie, and Evans, Julie. "Speak Up! Students Embrace Digital Resources for Learning." Knowledge Quest 39, no. 2 (2010): 20-27.

75. Teacher Librarian. "Technology Leadership: Kelly Czarnecki." Teacher Librarian, 37, no. 2 (2009): 75-76.

76. Dow, Mirah J. Ingram. "School Librarians Teach Subject Area 10: Computer and Information Sciences." School Library Monthly 27, no. 2 (2010): 5-8.

77. American Association of School Librarians (AASL) and Association for Educational Communications and Technology (AECT). Information Power: Building Partnerships for Learning. Chicago: American Library Association, 1998.

78. Donham, Jean. Enhancing Teaching and Learning: A Leadership Guide for School Library Media Specialists. New York: Neal-Schuman, 2008.

79. Neuman, Delia. "Research in School Library Media for the Next Decade: Polishing the Diamond." Library Trends 51, no. 4 (2003): 503-24.

80. American Association of School Librarians (AASL). Empowering Learners: Guidelines for School Library Media Programs. Chicago: American Association of School Librarians, a division of the American Library Association, 2009.

81. American Association of School Librarians (AASL). Standards for the 21st-Century Learner in Action. Chicago: American Association of School Librarians, a division of the American Library Association, 2009.

82. Roche, Rick. "Everything Popular Science." In Integrated Advisory Service: Breaking through the Book Boundary to Better Serve Library Users, edited by Jessica E. Moyer, pp. 143-81. Santa Barbara, CA: Libraries Unlimited, 2010.

83. Angier, Natalie. The Canon: The Whirligig Tour of the Beautiful Basics of Science. New York: Houghton Mifflin, 2007.

84. Saricks, Joyce G. The Readers' Advisory Guide to Genre Fiction. Chicago: American Library Association, 2009.

85. Moyer, Jessica; Donaldson, Christy; and Wagner, Casie. "Everything Science Fiction." In Integrated Advisory Service: Breaking through the Book Boundary to Better Serve Library Users, edited by Jessica E. Moyer, pp. 227-57. Santa Barbara, CA: Libraries Unlimited, 2010.

86. Buzzeo, Toni. The Collaboration Handbook. Columbus, OH: Libraries Unlimited, 2008.

87. Everhart, Nancy. "School Library Media Specialists as Effective School Leaders." Knowledge Quest 35, no. 4 (2007): 54-57.

88. Marcoux, Betty. "New Standards—Refreshing Our Work AGAIN!" School Library Media Activities Monthly 24, no. 7 (2008): 18-20.

89. Stripling, Barbara. "Inquiry Minds Want to Know." School Library Media Activities Monthly 25, no. 1 (2008): 50-52.

90. Bush, Gail. "Creativity Literacy: The Library Media Center as a Learning Laboratory." School Library Media Activities Monthly 24, no. 6 (2008): 24-26. 
91. Waugh, Amanda, and Subramanium, Mega. "Toward a Union of Fact and Fiction: Incorporating Science Fiction in the Science Curriculum." Paper presented at the Maryland Association of School Librarians annual conference, a division of Maryland Library Association, Ocean City, 2011.

92. Oberg, Dianne. "Libraries in Schools: Essential Contexts for Studying Organizational Change and Culture." Library Trends 58, no. 1 (2009): 9-25.

93. Fox, Laura H. "The Use of Web Resources by Elementary School Library Media Specialists." Master's paper, University of North Carolina, 2004. http://etd.ils.unc.edu/ dspace/bitstream/1901/132/1/laurafox.pdf.

94. Perrault, Anne Marie. "Making Science Learning Available and Accessible to All Learners: Leveraging Digital Library Resources." Knowledge Quest 39, no. 2 (2010): 64-68.

95. Aquino, Teresa L., and Levine, Elissa R. "Science and Math in the Library Media Center Using GLOBE." Knowledge Quest 31, no. 3 (2003): 40-41.

96. Cuban, Larry. Oversold and Underused: Computers in the Classroom. Cambridge, MA: Harvard University Press, 2003.

97. Zhao, Yong, and Frank, Kenneth A. "Factors Affecting Technology Uses in Schools: An Ecological Perspective." American Educational Research Journal 40, no. 4 (2003): 807-40.

98. Frank, Kenneth A.; Zhao, Young; Penuel, William R.; Ellefson, Nicole; and Porter, Susan. "Focus, Fiddle, and Friends: Experiences That Transform Knowledge for the Implementation of Innovations." Sociology of Education 84, no. 2 (2011): 137-56. 